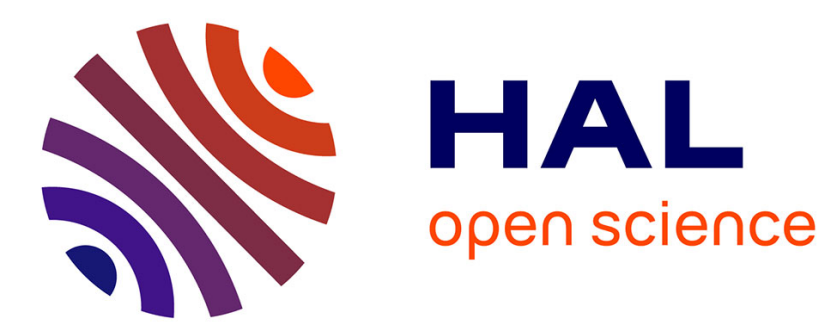

\title{
Knowledge at the boundary between science and society: a review of the use of farmers' knowledge in agricultural development
}

Nathalie N. Girard

\section{- To cite this version:}

Nathalie N. Girard. Knowledge at the boundary between science and society: a review of the use of farmers' knowledge in agricultural development. Journal of Knowledge Management, 2015, 19 (5), pp.949-967. 10.1016/S0141-8130(03)00058-8 . hal-02630286

\section{HAL Id: hal-02630286 \\ https://hal.inrae.fr/hal-02630286}

Submitted on 27 May 2020

HAL is a multi-disciplinary open access archive for the deposit and dissemination of scientific research documents, whether they are published or not. The documents may come from teaching and research institutions in France or abroad, or from public or private research centers.
L'archive ouverte pluridisciplinaire HAL, est destinée au dépôt et à la diffusion de documents scientifiques de niveau recherche, publiés ou non, émanant des établissements d'enseignement et de recherche français ou étrangers, des laboratoires publics ou privés. 


\title{
Knowledge at the boundary between science and society: a review of the use of farmers' knowledge in agricultural development
}

\author{
Nathalie Girard \\ INRA \\ UMR AGIR - Département SAD \\ 31326 Castanet Tolosan Cedex \\ FRANCE \\ ngirard@toulouse.inra.fr
}

\section{Purpose}

At the science-society boundary, farmers' knowledge (FK) is emphasized today as a way of designing more sustainable agricultural systems. Our objective was to build a review of innovation processes including FK from the viewpoint of knowledge management.

\section{Design/methodology/approach}

We performed a comprehensive and qualitative analysis of 273 articles drawn from the Web of Science.

\section{Findings}

We built four KM strategies on the basis of the objectives of these papers, the arguments used to justify the study of FK and their position regarding this knowledge: (1) Assessing FK to improve it; (2) Documenting FK to capitalize or legitimize it in development processes; (3) Using FK as a resource for innovation; and (4) Facilitating the sharing of sources of knowledge.

\section{Research limitations/implications}

We drew up research perspectives for each of them, some of which were related to the KM community and some of which extended the focus on political, legal or sociological aspects of knowledge production.

\section{Practical implications}

Our four categories of $\mathrm{KM}$ strategies revealed the importance of legitimization processes of practitioners' knowledge at science-society boundaries, whereas such processes are often neglected by classical KM methodologies.

\section{Social implications}

Our work questions the category of "practitioners' knowledge", stressing the need to go beyond the dichotomy between scientific and empirical knowledge.

\section{Originality/value}

Even if FK has been used since the 1970s to promote more endogenous innovation processes as opposed to classical science-driven innovation processes, no review has yet been done of the use of FK in the development of agricultural systems.

\section{Keywords}

Practitioners' knowledge; review; technical system; agriculture; innovation process; science-society boundary

Paper type: research paper 


\section{INTRODUCTION AND THEORETICAL BACKGROUND}

While knowledge production has longer been confined to science alone, the emergence of a new contract between science and society (Nowotny et al., 2001) has renewed knowledge management and production stakes. These authors describe a more complex circulation of knowledge at the boundary between science and society (referred to as "mode 2") in which knowledge production is a participative process involving society from the problem formulation to the assessment of the results' quality. With the aim of enhancing participative democracy, an increasing number of approaches takes into account the plurality of knowledge of the different stakeholders concerned with, for example, knowledge of local stakeholders (elected officials, users, associations, inhabitants, etc.) concerned with challenges related to territorial management (Girard, 2013). Others argue that knowledge production processes must involve the stakeholders the most concerned by the problem being treated like, for example, patients and their families in the management of health problems (Bate and Roberts, 2002). Nevertheless, this mode 2 encompasses various knowledge production and management processes. As a result, recognizing the existence of this mode is not sufficient to describe the many different ways in which various sources of knowledge, and especially knowledge coming from stakeholders and/or practitioners, are used to foster innovation.

In the field of Knowledge Management (KM), KM strategies have been described by emphasizing either the business processes, the end results or the knowledge creation processes (Haggie and Kingston, 2003). With this latest view, the most influential classifications of KM combine knowledge accessibility and knowledge transformation, leading to categorize KM strategies as being "either human or system oriented" (Choi and Lee, 2002), close to socialization or codification approaches (Hansen et al., 1999). The roots of these classifications can be found in seminal works on the nature of knowledge, either tacit or explicit (Polanyi, 1966), which brought Nonaka and Takeuchi (1995) to formalize four conversion modes between types of knowledge such as socialization, externalization, combination, and internalization. In this view, innovation occurs as a result of the flow and transformation of tacit and explicit knowledge, giving a great importance to practitioners' knowledge. This knowledge, derived from action, has been theorized for a long time as experiential knowledge (Kolb, 1984), i.e. knowledge that is closely linked to the mastering of a practical activity (Tsoukas and Vladimirou, 2001). It expresses the way in which practitioners appropriate available information in their environment in order to progressively transform it into individual knowledge and professional routines (Tsoukas and Vladimirou, 
2001). This practitioners' knowledge has long been valued within firms as social capital or a competitive advantage. It is thus seen as a resource that allows to deal with uncertainty in knowledge-intensive firms (Ditillo, 2004) or to design an innovative type of marketing based on customers' experience (Schmidt, 1999). By looking at the firm as a "knowledge processor" (Cohendet and Llerena, 2005), it is, above all, at the firm scale that KM strategies have been studied. Various typologies of KM strategies have been proposed, some of them like Denford and Chan (2011) trying to combine previous typologies to draw ideal knowledge strategy profiles. Other works such as Kamara et al. (2002) propose a framework for selecting a knowledge management strategy that is appropriate to the organisational and cultural context of an organisation, but all these proposals remain at the firm level, thus questioning their relevance outside the boundaries of a firm. The few works which consider inter-organizational relationships (such as Hedlund, 1994) remain implicitly focused on a firm-centered model with its providers and customers.

More recently, in the search for innovative models of knowledge organization, research in $\mathrm{KM}$ has been oriented towards distributed models of knowledge production, as can be seen by the popularity of the theory of Communities of Practice (Wenger, 1998) or formalizations in terms of "epistemic communities" (Cowan et al., 2000), "knowledge networks" (Swan et al., 1999) or "practice networks" (Agterberg et al., 2010). However, these new models of knowledge circulation and production have been mainly studied as intra-organizational processes, even if they sometimes come from the study of geographically dispersed development organizations; as a result, they do not really take account of the diversity of existing KM practices and strategies in areas such as health, the environment and agriculture, where knowledge is produced, translated, discussed and shared through inter-organizational processes at the boundary between science and society. We thus hypothesize that such situations are difficult to describe using only the codification and personalization strategies of Hansen et al. (1999) even if they are often considered as generic strategies.

Within an inductive process, the aim of this article is therefore to describe KM strategies calling upon practitioners' knowledge at the boundary between science and society, in a domain (agriculture). We chose this domain because the innovation interface between science and society is the heart of many crucial issues regarding knowledge production, with a high degree of controversies arising from coexisting and contrasted innovation systems and knowledge regimes (Barbier and Elzen, 2012). Moreover, the agricultural domain is largerly under-investigated in KM. Our research strategy was to carry out an inductive and qualitative 
analysis and synthesis of scientific articles that mobilize this knowledge in this particular area of activity, thus drawing a picture of KM strategies in the domain.

\section{RESEARCH STRATEGY}

\subsection{Qualifying diversity in the management of practitioners' knowledge in agriculture}

In the area of agricultural development, innovation processes have long been debated, between the science-driven "Transfer of Technology"[i] and the advocates of a more "indigenous" development, emphasizing the innovations that come from the practitioners themselves. By placing readjustment and action learning processes at the core of management, the current "agroecological transition" of agricultural systems renewed the importance given to local conditions and knowledge acquired through practices in the field, by the practitioners themselves (Girard, 2014). Agricultural research is therefore at the heart of current debates about the role of science in the production of innovation and is looking for new knowledge production pathways, making participatory-oriented approaches and partnerships with the farming sector a strategic question for agronomical research. This is the basis that is used to promote the integration of farmers' knowledge (FK) in recent reports on the challenges and evolution of agronomic research at the worldwide (IAASTD, 2008) and at the European (SCAR, 2011) levels. However, no study has yet revealed the diversity of this research in terms of practitioners' knowledge management. The aim of this article is therefore to describe in an inductive process this diversity of KM strategies in research that calls on FK, in an area where innovation processes are nowadays expected to cross the boundary between science and society.

\subsection{A comprehensive literature review}

Following the methodology proposed by Schlichter and Kraemmergaard (2010), already used by Ergazakis et al. (2013) for KM research, the analysis was carried out in two stages, i) the search and selection of papers to include in the review, ii) the categorization and classification of papers.

\subsubsection{Building bibliographic bases}

The strategy chosen consisted of building a bibliographic database of scientific articles dealing with FK, in the social sciences as well as in the biological and agronomic sciences. At the end of 2013, the following request was launched on the ISI's Web of Science database: 
$\left(\left(\mathrm{TI}=\left(\right.\right.\right.$ know $\left.^{*}\right)$ AND TI=(indigen* OR local* OR experient* OR empiri* OR tradition* OR farmer*) AND TS=(farm* OR agric* OR livestock* OR husbandry* OR crop* OR agronom* OR pasto*))) AND Document Types=(Article)

The aim of this request was to form a large database (without any restrictions as to journal or language), made up of articles dealing with the steering of agricultural production (restriction on topic), but filtering articles whose subject matter revolved around practitioners' knowledge about farming activities (restrictions on title). In order to be as exhaustive as possible, we included all of the identified descriptors of FK, including "indigenous", "traditional", "local", "empirical", and even "experiential".

A bibliographic database of 452 references was thus obtained. It was then sorted so as to conserve only articles with an abstract. Moreover, articles whose subject matter did not focus on agricultural activities were considered to be outside of the scope of this study. Using the title and the abstract, we thus eliminated articles dealing with natural resource management when there was no link to the management of an agricultural production process (e.g. forest management). Similarly, articles dealing with farmers' perceptions of climate change, as well as those focused on food transformation processes, were eliminated.

On the basis of their abstracts, review papers (35 articles) were distinguished from empirical studies which were grouped into a second bibliographic database of 282 empirical articles. The rest of this article is focused on the analysis of this second bibliographic database, whereas some of the review articles are referred to in the discussion.

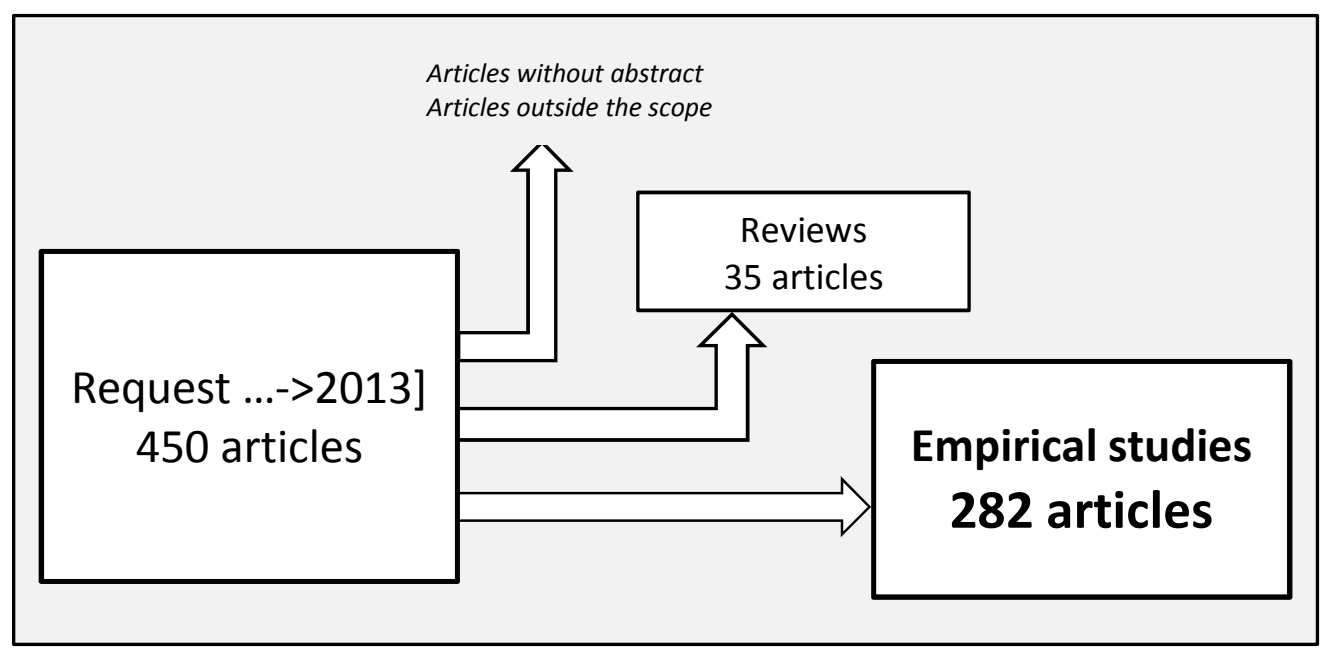

Figure 1: Building bibliographic databases 


\subsubsection{Categorizing and classifying empirical studies}

With the aim of describing the strategies of the use of practitioners' knowledge, the study was performed by a qualitative analysis of the articles' contents rather than a more classic and quantitative bibliometric analysis. Moreover, the choice was to carry out an inductive process without using the generic KM strategies formalised in intra-organizational situations.

The analysis of the empirical studies of the second bibliographic base was thus performed with an iterative process, grouping similar studies, extracting relevant attributes to describe these groups and categorizing them in KM strategies. Due to the subjective nature of such inductive analysis, as well as the enormous variability of terms used to refer to practitioners' knowledge, the analysis began with a thorough content analysis of 30 papers $(10 \%$ of the empirical studies), thus developing a framework containing the items to which compare the following papers. With an abductive-inductive process (Glaser and Strauss, 2009), attributes were progressively formalized as being relevant to differentiate the articles. They were further tested by classifying several articles, and then reviewed and reclarified, leading to a stabilised analytical framework.

More precisely, this first analysis of 30 papers revealed the importance of their objectives of Knowledge Management: our analytical framework thus contained both the stated objectives of these articles that study and/or mobilize FK (for what purpose?), as well as the arguments put forth to justify studying them and/or mobilizing them (why?). Taking into account the contrasting knowledge regimes and strong controversies about knowledge status in agriculture, their position in relation to the various knowledge sources was also added (definition and forms of validation). Finally, this categorization has been used to classify all the empirical studies of the second database (using their abstracts and sometimes their introductions-conclusions) into four groups presented in detail in the Results section.

Parallel to this classification, we eliminated methodological articles whose objective was not to use or mobilize FK but, instead, to test or develop techniques and methodologies that would make it possible to mobilize FK (eight articles, plus seven others were linked to the four strategies described below). We thus found articles that proposed composite methodologies, along with articles more specifically testing a technique like scenarios, fuzzy logic or cognitive maps. However, these studies are not published in journals in the areas of "Information Science" or "Computer Science". The analysis of the 273 remaining articles (outside of purely methodological articles) is the focus of the Results section. 


\section{RESULTS: KM STRATEGIES BASED ON PRACTITIONERS' KNOWLEDGE}

On the basis of these 273 articles, we formalized four different strategies implemented to call on practitioners' knowledge in agricultural research (Table 1):

1 - To assess FK in order to improve it

2 - To document FK in order to capitalize on it or to legitimize it in the development process

3 - To use FK as a resource for innovation

4 - To encourage the sharing of knowledge between stakeholders in order to increase the effectiveness of development measures

\subsection{Four strategies to deal with practitioners' knowledge}

\subsubsection{STRATEGY 1: To assess FK in order to improve it}

These articles see agricultural development as a technical problem that can be resolved through the diffusion of scientific knowledge. Most of them are based on the assumption that FK is imperfect, insufficient or unsuited, or even responsible for damage to the environment: practitioners' knowledge is therefore seen as a limiting factor to the modernization of agriculture within a vision of knowledge qualified as a "deficit model of knowledge" by critical researchers as Rios-Gonzalez et al. (2013).

Some of these articles thus begin by describing FK in an area considered from the scientific viewpoint as limiting the performances of agricultural enterprises, whether they be economic or environmental. This description is sometimes linked to an assessment of the effectiveness of practices implemented and/or of the scientific validity of the knowledge they are based on (e.g., Bonny and Vijayaragavan, 2001). Based on the observation of the failure of development programs, many articles hold that it is necessary to study FK to then be able to improve it. With the clear aim of Technology Transfer, some articles thus assess FK in relation to a technology or to "good practices" to improve their acceptability (e.g., Lewis et al., 2010, concerning GMOs). Within a more explanatory approach, other articles attempt to link FK to social determinants or to the sources of information used (Belgrave et al., 1990) in order to explain the reason for an adoption, considered to be insufficient, of technologies produced by science. Some authors use this explanation to deduce the factors to be considered to improve this adoption (e.g. Lewis et al., 2010), or forms of knowledge diffusion to be developed (Belgrave et al., 1990). 
Table 1: Four strategies for calling on practitioners' knowledge, illustrated using examples (IK = Indigenous Knowledge)

\begin{tabular}{|c|c|c|}
\hline Strategy & $\begin{array}{l}\text { Arguments and position in relation } \\
\text { to practitioners' knowledge }\end{array}$ & Examples \\
\hline $\begin{array}{l}\text { 1. To assess } \\
\text { practitioners' } \\
\text { knowledge in } \\
\text { order to improve } \\
\text { it }\end{array}$ & $\begin{array}{l}\text { - practitioners' knowledge is imperfect, insufficient or } \\
\text { unsuitable: it constitutes a limiting factor to development } \\
\text { - this knowledge leads to practices and technical systems that } \\
\text { are not sustainable } \\
\text { - it must be improved by diffusing knowledge, technologies } \\
\text { or "good practices" designed by science } \\
\text { - studying practitioners' knowledge makes it possible to } \\
\text { improve supports and education to improve this knowledge }\end{array}$ & $\begin{array}{l}\text { "classifying them into rational and irrational practices based on the evaluation of a group of scientists and } \\
\text { agricultural extension officials working in the area" (Bonny and Vijayaragavan, 2001) } \\
\text { "determine baseline knowledge and identify knowledge gaps of farmers" (Nampanya, 2010) } \\
\text { "local people's knowledge and economic realities are the main factors, as well as natural conditions, that drive this } \\
\text { land degradation" (Binh et al., 2008) } \\
\text { "farmers need to be educated [...] to ensure sustainable [...] control" (Nyeko et al., 2002) } \\
\text { "Experience has shown that to ensure IPM adoption, the complexities of local agro-production systems and context- } \\
\text { specific folk knowledge need to be appreciated" (Wyckhuys and O'Neil, 2007) } \\
\text { "Farmers' knowledge [...] as prerequisites to IPM adoption" (Hashemi et al., 2008) } \\
\text { "providing training based on farmers' real needs" (Kiptot et al., 2006) }\end{array}$ \\
\hline $\begin{array}{l}\text { 2. To document } \\
\text { practitioners' } \\
\text { knowledge to } \\
\text { capitalize on it or } \\
\text { to legitimize it in } \\
\text { the development } \\
\text { process }\end{array}$ & $\begin{array}{l}\text { - practitioners' knowledge is derived from a long co- } \\
\text { evolution with their environment } \\
\text { - practitioners' knowledge is part of a cultural and social } \\
\text { heritage to be protected; it must be documented } \\
\text { - it supports sustainable technical systems and plays a central } \\
\text { role with respect to sustainability issues } \\
\text { - it is therefore legitimate and becomes a militant factor for } \\
\text { endogenous means of development }\end{array}$ & $\begin{array}{l}\text { "their knowledge of rangeland plants and principles of sustainable rangeland management is indigenous and based } \\
\text { on centuries of experience and observation" (Ghorbani et al., 2013) } \\
\text { "limited intergenerational transfer of IK currently threatens its existence in the longer term" (Speranza et al., 2010) } \\
\text { "local and traditional knowledge is valuable, adaptable and necessary in coping with risk and uncertainty in a } \\
\text { changing world" (Beckford and Barker, 2007) } \\
\text { "integration and inclusion of farmer perspectives in [...] national agricultural development planning and policy } \\
\text { formulation processes" (Dawoe et al., 2012) }\end{array}$ \\
\hline $\begin{array}{l}3 . \quad \text { To use } \\
\text { practitioners' } \\
\text { knowledge as a } \\
\text { resource for } \\
\text { innovation }\end{array}$ & $\begin{array}{l}\text { - innovation and R\&D processes can be improved using } \\
\text { practitioners' knowledge; this knowledge is a source of } \\
\text { innovation } \\
\text { - scientific knowledge, like that of practitioners, is limited; } \\
\text { they are complementary } \\
\text { - both practitioners' knowledge and scientific knowledge } \\
\text { should be used to improve the performance of technical } \\
\text { systems, local decision-making processes or environmental } \\
\text { management } \\
\text { - practitioners' knowledge makes it possible to design better } \\
\text { models }\end{array}$ & $\begin{array}{l}\text { "research can identify promising IK practices which as a result are extended over much wider geographical areas" } \\
\text { (Ouedraogo and Bertelsen, 1998) } \\
\text { "The local knowledge provided insights in present management strategies, whereas the scientific information } \\
\text { demonstrated the constraints on present land use systems" (Gobin et al., 2000) } \\
\text { "the local and technical knowledge integration is necessary, with the goal of reaching a shared vision of reality, and } \\
\text { synergy, at the time of decision making" (Hernández-Hernández et al., 2011) } \\
\text { "how to combine conservation and local development objectives through the involvement of farmers and the } \\
\text { recognition of local knowledge in tree management" (Marie } \text { et al., 2009) } \\
\text { "integrating farmer knowledge, precision agriculture tools and crop simulation modeling" (Oliver et al., 2010) } \\
\text { "study the knowledge farmers use to manage their crops and discusses its consequences for the design of crop } \\
\text { management supports" (Cerf, 1996) }\end{array}$ \\
\hline $\begin{array}{l}\text { 4. To encourage } \\
\text { the sharing of } \\
\text { knowledge } \\
\text { between } \\
\text { stakeholders in } \\
\text { order to increase } \\
\text { the effectiveness } \\
\text { of development } \\
\text { projects }\end{array}$ & $\begin{array}{l}\text { - practitioners' knowledge is part of a historical and social } \\
\text { dynamic: it circulates between generation, between old and } \\
\text { new practitioners, between practitioners and scientists } \\
\text { - practitioners' knowledge improves the effectiveness of } \\
\text { development projects, and vice-versa } \\
\text { - we must look at how practitioners' knowledge can } \\
\text { contribute to development projects }\end{array}$ & $\begin{array}{l}\text { "Both external and farmer-derived sources of knowledge [...] were transferred through informal advice networks" } \\
\text { (Isaac et al., 2007) } \\
\text { "more dialogue [...] between ranchers and scientists [...] could expand and strengthen the informal social networks } \\
\text { through which much rancher knowledge is shared " (Knapp and Fernandez-Gimenez, 2009), "farmers' access to and } \\
\text { use of information [...] within the context of their interpersonal social networks" (Sligo et Massey, 2007) } \\
\text { "policy knowledge cultures can give voice to farmers' ways of knowing nature with benefits both for them and } \\
\text { nature itself" (Morris, 2006) } \\
\text { "PRA techniques can be an effective strategy for developing metacognitive behaviour among farmers" (Shahvali and } \\
\text { Zarafshani, 2002) } \\
\text { "agronomist-farmer [...] encounters provide a platform for the facilitation of farmer learning in their transition to } \\
\text { more sustainable practices" (Ingram, 2008) }\end{array}$ \\
\hline
\end{tabular}


Some authors deduce from this the necessity to train and educate farmers (e.g., Nyeko et al., 2002) in order to improve their management ability due to their "lack of knowledge", making it possible to identify farmers' training/information needs. More evaluative articles try to determine the impact of training programs or to compare different methods of diffusion or, more generally, to assess the effect of development programs on FK.

\subsubsection{STRATEGY 2: To document FK to take advantage of it or to legitimize it in the development process}

This group of articles is based on a critical analysis of science and technology and "their general ineffectiveness in significantly improving the living standards of the majority of the world's population over the last 40-50 years" (Briggs et al., 1998). Putting FK in the forefront is therefore a means of legitimizing and exploring alternative development models that directly involves the farmers themselves.

Claiming that their practical knowledge is the result of a long co-evolution between them and their environment, some articles argue that the sustainability of this knowledge and of these technical systems are given facts to justify their ethnographic study. Others, in contrast, attempt to show that it is at the basis of production systems that are beneficial to the environment or resilient in relation to climate change. They conclude that this knowledge thus has a central role to play in meeting the current environmental challenges, particularly because "the environmental knowledge embedded in local cultures provides a long-term perspective on land use and management not otherwise available" (WinklerPrins, 2003).

Recognition of this role therefore highlights the challenge of maintaining these production systems and the local culture that supports them, particularly for pastoral livestock systems (e.g. Fernández-Giménez and Estaque, 2012). Starting with the observed decline of this knowledge in an otherwise industrialized world (Speranza et al., 2010), some authors argue for the protection and capitalization of this knowledge. In these articles, practitioners' knowledge is dealt with as a naturalized object that should be documented and taken advantage of ${ }^{[i i]}$. Consistent with knowledge capitalization within firms that can be interpreted as knowledge privatization projects (Pesqueux, 2009), these studies can be analyzed as empowerment policies for "indigenous" populations in developing countries, or as the protection of the rights of indigenous peoples in relation to the technologies produced by industrialized countries (Marin, 2011).

Such documentation of FK can be a first step in the innovation process. Sixteen articles in this group (i.e., a third) were classified as overlapping this strategy and the following one. 
Sometimes, when it can be established that little is known about a given subject, these overlapping articles consist, above all, in describing FK in detail within an ethnographic approach, to be able to compare it with scientific knowledge or to derive new prospects or recommendations from it in terms of possible future research topics or projects.

\subsubsection{STRATEGY 3: To use FK as a resource for innovation}

In line with the initial project of the Farming Systems Research (FSR) community that recognize the increased acceptance of local knowledge within science ${ }^{[i i i]}$, these articles attempt to orient research towards the themes and issues that are the most relevant for the people involved (Gibbon, 1994). They all aim at improving innovation, research and development processes using FK, some of them being "position papers" (e.g., Doré et al., 2011) claiming that using FK is a new way of producing agronomical knowledge. Nevertheless, there is a diversity of viewpoints regarding the innovation process. For some authors, relying on practitioners' knowledge means increasing the acceptability of innovations; for others, it is a way to identify or develop innovations from the "bottom-up" at a minimum $R \& D$ cost.

Many of the articles in this group aim at integrating FK and knowledge produced by science to improve the effectiveness of decision processes or environmental management. We also found many articles that describe FK and compare it to that of scientists, allowing them to identify what is shared or not between these two knowledge categories and to consider to what degree it is complementary or contradictory. Some authors even identify empirical knowledge to be validated by scientific processes, thus being close to articles in strategy 1 .

Others focus on ways to create synergy between FK and scientific knowledge (Briggs et al., 1998; Girard and Navarrete, 2005). We also find some articles on modeling that attempt to integrate FK into an artifact with a scientific knowledge basis like, for example, "integrating farmer knowledge, precision agriculture tools and crop simulation modelling to evaluate management options for poor-performing patches" (Oliver et al., 2010). The aim of these articles is to formalize FK to design or parameterize decision and learning models, to make up for the knowledge gaps in scientific models.

3.1.4. STRATEGY 4: To encourage the sharing of knowledge between stakeholders in order to increase the effectiveness of development projects

The perspective common to the articles in this group is that by promoting the sharing of knowledge between the different stakeholders involved in the development process (and, 
therefore, the farmers), the effectiveness of these processes will be increased. These articles thus consider knowledge as a process. Most of these articles reintroduce the neglected aspects of time dynamics in the construction of knowledge and insist on the dynamic, historical and social dimensions of the construction of FK. By focusing on long periods of time, some of the articles aim at describing the knowledge transmission process between farmers in view of the major socio-economic changes in farming, whether it be knowledge transmission between generations or between old and new farmers. Some of the articles adopt a highly macro vision of knowledge, like Tripp (1993) who examines the challenges involved in public agricultural research in Ghana. We also found genealogical analyses of knowledge construction and the technologies that accompany agricultural production, with discontinuities, controversies and conflicts concerning indigenous knowledge and its hybridization with other sources of knowledge. Information sources used by farmers, as well as the individual knowledge sharing processes within interpersonal networks between farmers, are also studied (Sligo and Massey, 2007), as is the hybridization of different sources (Munyua and Stilwell, 2013).

Other articles focus on the role of FK in environmental policies like, for example, Morris (2006) who shows that the codified knowledge underlying agro-environmental measures does not necessarily marginalize other sources of knowledge. Similarly, Riley (2008) explored how farmers derive experiential knowledge from their context of action and how this knowledge can be in conflict with knowledge encapsulated in environmental conservation measures. These articles hint at or, even explicitly promote, like Shepherd (2011), the need for a "politics of knowledge" in environmental protection projects.

Consistent with Nowotny et al. (2011)'s mode 2, many articles in this group explore the means for partnerships between farmers, researchers and development agents, thus "challenging the boundaries between local and scientific knowledge" (Millar and Curtis, 1999), sometimes with political analyses of "knowledge inclusion" (Srang-iam, 2013). These analyses recall those of Hiruy and Eversole (2013) of the translation and mediation processes between rural communities and development institutions. In contrast with the articles in strategy 1, these articles examine the adoption of technologies from a critical point of view, from the standpoint of farmers' learning processes, considered as "'reflexive' actors who actively negotiate between 'expert' and 'local' knowledge" (Kaup, 2008). 
3.2. Drawing a picture of the KM strategies implemented to cross the boundary between science and practice in agriculture

The 273 empirical studies of our database are distributed as shown in Figure 2. The largest part of the empirical studies (102 articles i.e., over two thirds) mobilize FK for the purpose of innovation (group 3), whereas almost a third of it falls under the first strategy ("assess to improve"). With 48 articles, group 2 (“document to capitalize on and/or to legitimize") represents $17 \%$ of the database, thus being at the same level as group 4 ("share") with 49 articles, i.e., almost $20 \%$ of the empirical studies.

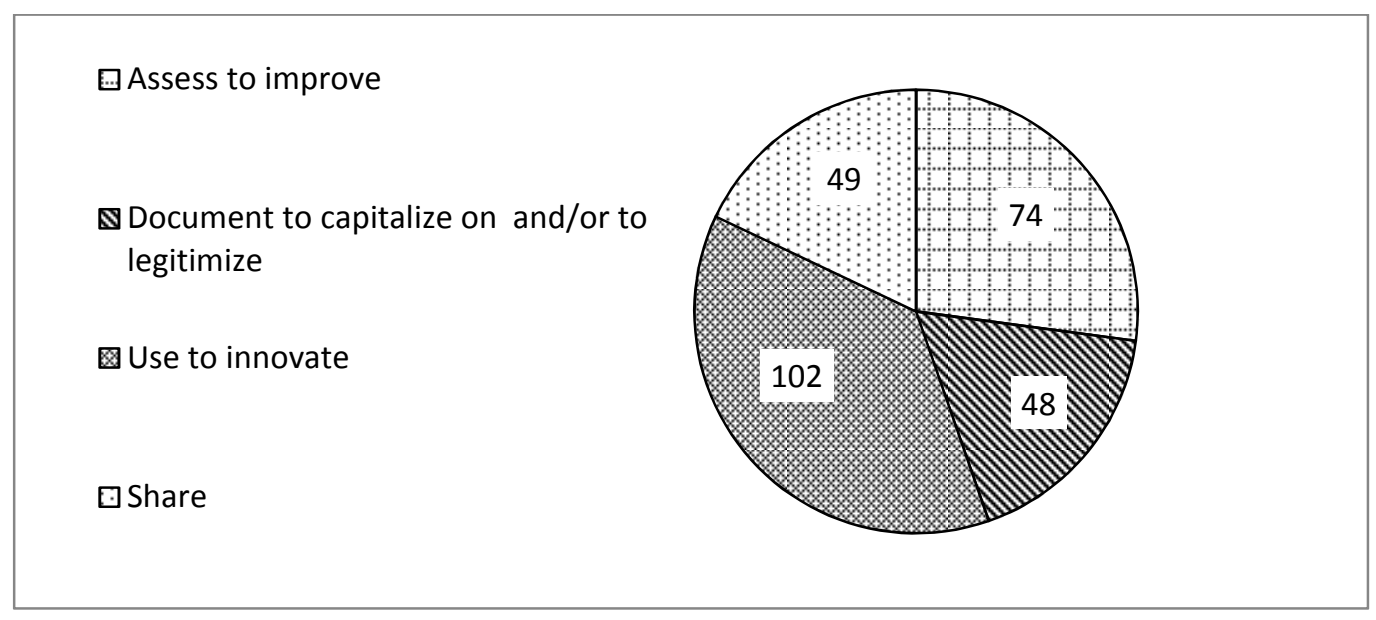

Figure 2: Distribution of the empirical studies into four strategies

A temporal analysis shows that these four categories of articles have appeared concurrently since the 1990s, with a similar volume of publications over the years (Figure 3). Contrary to what we would have thought, the articles under strategy 1 (assess to improve) are not the sign of a bygone era of Technology Transfer. They have been published on an almost continuous basis since 1989 (with a minimum of one article published per year), and that stabilized at seven articles per year in recent years. The three other groups have also been published on an almost continuous basis since the 1990s. Group 2 shows a peak in 2012, without being able to explain this phenomenon by the publication of a special issue (eight articles in eight different journals). 


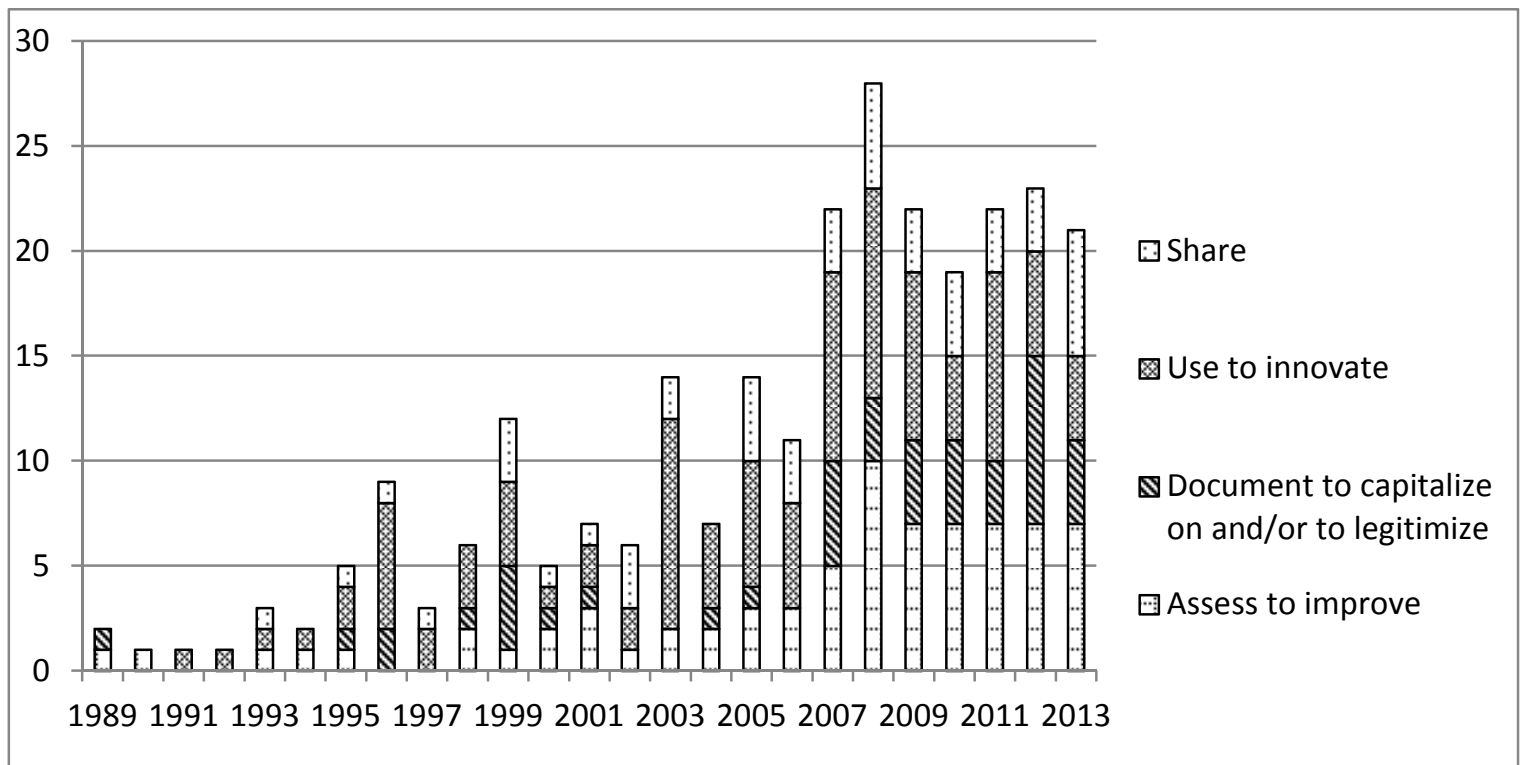

Figure 3: Evolution of the numbers of empirical studies in each of the four strategies

These four strategies can more or less be linked to types of journals and disciplines. Articles in group 1 are mainly published in journals specialized in areas with a high technical content , like plant health (Crop Protection and the International Journal of Pest Management) and dairy production (Indian Journal of Animal Research). Articles in group 2 are more commonly published in journals with a relatively militant editorial policy, such as the Indian Journal of Traditional Knowledge (with more than half of the articles published by this journal on this theme), a journal that explicitly promotes the validity of traditional knowledge and the necessity of documenting it ${ }^{[\mathrm{iv}]}$. Groups 3 and 4 generally show a high diversity in terms of publication range and a pluridisciplinary orientation, often falling into the Social Sciences and Humanities, particularly for strategy 4.

In terms of the geographic distribution of the areas studied, most of the articles in strategies 1 , 2 and 3 focus on developing countries ${ }^{[v]}$, which therefore see the coexistence of approaches with radically opposed positions in relation to $\mathrm{FK}$, with strategy 1 considering practitioners' knowledge as a limiting factor, whereas strategy 2 defends it as a militant factor with the aim of empowering poor farmers in these countries. Nevertheless, despite the large number of articles arguing for the integration of farmers' viewpoint in development policies, Briggs (2013) shows that these studies have had little effect, thus criticizing the use of indigenous knowledge that is "often drawn into development by both theorists and development institutions in a very limited way, failing to engage with other ways of perceiving development, and thus missing the possibility of devising more challenging alternatives" 
(Briggs and Sharp, 2004). On the contrary, the number of articles in group 4 dealing with developed and developing countries is roughly the same.

\section{DISCUSSION}

4.1. A categorization of knowledge management strategies at the boundary between science and practice

What is the genericity of these four strategies in terms of knowledge management? To some degree, we found the two strategies of codification and personalization of Hansen et al. (1999) (group 4, in particular, being very close to a personalization strategy) or the technocratic or behavioral knowledge strategies of Earl (2001). In the same way, our categorization partially covers the knowledge management categories proposed by Ermine (2000): to capitalize on the existing knowledge heritage (some of the articles in group 2 with a view to documentation), to share this knowledge to increase organizational efficiency (close to group 4) and to create new knowledge for the purpose of innovation (close to group 3 ). However, all these KM strategies were formalized within a firm's strategy, in particular putting forward the balance between internal and external learning (Bierly and Chakrabarti, 1996). As a result, they do not take the legitimization process of practitioners' knowledge into account, perhaps taken for granted when a KM approach is implemented within a firm, but often necessary in innovation processes between science and society. We can therefore analyze some of the articles in group 2 from the angle of power relationships in rural areas, which are particularly crucial when agricultural development models are questioned. More largerly, it questions the Knowledge Management literature, which to date, has insufficiently addressed the construct of power (Gordon and Grant, 2005). On the other hand, as suggested by Scheepers et al. (2004), it would be interesting to add a temporal dimension to our analysis since organizations are sometimes forced to modify their knowledge management strategy over time and to adopt mixed strategies. For this, it would be necessary to carry out a more indepth analysis to determine whether or not series of publications by the same authors or over the same area but with different strategies exist. Finally, articles in group 1 (assess to improve) do not appear in the classical typologies of $\mathrm{KM}$ strategies, whereas training strategies within companies that emphasize skills more than knowledge could be analyzed from this viewpoint. 


\subsection{Limitations}

The limitations of this analysis are primarily linked to the method chosen. First, the choice of the Web of Science database may have limited our research to certain journals while excluding others such as the journal Knowledge Management for Development (e.g., Javier Cabero and Willem van Immerzeel, 2007) or the Electronic Journal of Knowledge Management (e.g., Soulignac et al., 2012) that published some articles about FK. Likewise, the formulation of the request and the terms chosen eliminated articles dealing with regional development through knowledge creation in agricultural firms (e.g., Galindo, 2007) and relatively close articles focusing on FK, but using keywords like perception, practices, representations. Thus, in many of the empirical articles studied, the term "practices" is used in the same way as that of knowledge, or associated in the form of "Indigenous Knowledge practices" (e.g., Ouedraogo and Bertelsen, 1998). Consequently, requests formulated in this manner probably under-evaluated the total number of articles, and particularly the articles with the strategy 4 that use keywords such as learning processes and participative approaches associating researchers and farmers.

Like for all classification processes, it appeared that some articles did not completely correspond to one and only one of the defined strategies (articles thus classified between two strategies were treated separately), or were unclassifiable. Nevertheless, the small number of unclassifiable articles and the robustness of the classification of others confirmed our choice of the four strategies. Moreover, the classification of articles on the basis of the objectives stated by the authors in the abstract obscures the actual processes for managing practitioners' knowledge in these empirical studies: it is one of the perspectives of this article to delve into this aspect over a small sample of empirical articles.

\subsection{Questioning the category of "practitioners' knowledge"}

Finally, the category "practitioners' knowledge" (farmers, in our study) was naturalized in this article for the needs of the study, which implies some limitations. In particular, this category includes some ambiguity since it covers both the nature itself of this knowledge as such (knowledge produced in the course of action, experiential, etc.) and its possession and/or production by a particular category of stakeholder (the "practitioner"). Nevertheless, we did not remove this ambiguity whereas we already know that these stakeholders possess a much more hybrid type of knowledge (strategy 1 actually explicitly aims at "improving" this knowledge by making the stakeholders appropriate knowledge derived from science!). When 
trying to investigate the boundary between science and practice, this category - and its hybrid character - thus remain to be questioned, in keeping with articles that include a critical reflection on the naturalization of knowledge categories, arguing that it is necessary to go beyond the dichotomy between scientific and local knowledge (Agrawal, 1995) and that hybridization often exists between the two (Thomas and Twyman, 2004). Other authors have shown that local knowledge is not necessarily sustainable and should not be seen as a green alternative to scientific knowledge (Murdoch and Clark, 1994), thus highlighting the danger of mystifying this local knowledge. More broadly, it would be necessary to question the different qualifications of knowledge associated with a practice ("indigenous", "local", "empirical", etc.), where each one is linked to a scientific or even political trend (Agrawal, 1995). Even if distinguishing types of knowledge helps to delineate problems in rural and sustainable development, the boundaries between these types are not very sharp and there are various exchanges and interaction between them (Bruckmeier and Tovey, 2008). However, most of the empirical studies remain within a perspective where the category of FK (to be "collected", captured" and "conserved") is naturalized without questioning its construction process. In particular, this notion of knowledge as a resource that must be shared obscures the processes that made it possible to make it manageable, and that calls for the conceptualization of "indigenous knowledge more as a way of knowing, or as a process or practice, with less emphasis on content and more on epistemology" (Briggs, 2013). Along the same lines, Bruckmeier and Tovey (2008) suggest "to open the analysis towards a more process-oriented view of 'knowledge in action', in its generation, dissemination and application processes". This statement is consistent with other review papers identified, like Baars (2011) who proposes to conceptualize these processes in a new research approach that he refers to as "experiential science", thus clearly claiming to outshine the boundary between science and practice. Finally, taking seriously the question of knowledge management at the boundary between science and practice should encourage scholars to recognize that the gap between theory and practice may be a knowledge production problem and to engage in methods in which researchers and practitioners coproduce knowledge that can advance both theory and practice in a given domain (Van de Ven and Johnson, 2006).

\section{PERSPECTIVES AND CONCLUSION}

This bibliographic analysis opens up new prospects for research in terms of KM, which largely depend on the objectives laid out in terms of research and the use of practitioners' knowledge. 
Thus, for strategy 1 (assess to improve), practitioners' knowledge is considered as a limiting factor from a positivist outlook where knowledge is only legitimate once it has been scientifically validated. Within this outlook, KM issues are limited to questions of scientific validation. For strategy 2 (document to capitalize or legitimize knowledge in the development process), practitioners' knowledge is considered as a heritage to be conserved and/or an argument for a more endogenous development. Beyond the clarification of this knowledge and its storage in databases, the questions that arise as a result of such approaches are more of a political (like the forms of development studied by developmental anthropology), legal (e.g., pertaining to intellectual property) and sociological (studies on the type or relationship between science and society) nature. For these two strategies, what is of utmost importance is the managerial and political implications of the tools designed: they represent the rationalization supported (and, implicitly, the development project) and the performance criteria used, i.e., the relationships between knowledge and action induced by these tools which are only very rarely the object of an in-depth analysis. As a consequence, all tools that are used to accompany the development of technical systems should be analyzed from the critical viewpoint of their design context (Briggs and Moyo, 2012). For example, tools used in strategy 1 should be looked at with respect to the dominant knowledge paradigm called the "Knowledge-Based Bio-Economy" (Barbier and Elzen, 2012) which "promotes the role of the life sciences in technoscientific development as a means of achieving a more efficient use of renewable".

From the point of view of KM, the articles that appear to be the most interesting are those that acknowledge two-way processes between science and practice, i.e., groups 3 (use to innovate) and 4 (promote sharing). In these groups, the links between the different forms of knowledge (in particular, the link between scientific and experiential knowledge) are explicitly questioned and the approaches are more explicitly linked to management practices (modeling, generalization, sharing, etc.) of knowledge linked to innovation challenges. In particular, it puts forward the need for research which really deals with the question of the generalization of local knowledge to make it usable in similar situations. Given the transition challenges of technical systems, this also implies the acceptance - and management - of ignorance as a source of organizational performance, as suggested by Roberts (2013). Finally, it opens a vast territory of research questions about how we can support collective processes that alternate and combine the use of existing knowledge, produced within a specific knowledge paradigm, and the exploration of new pathways (March, 1991). This means cultivating some 
ambidexterity (Raisch et al., 2009) by creating learning contexts with ambidextrous KM initiatives at micro-level (Filippini et al., 2012) as well as designing tools which are relevant to characteristics of organizational ambidexterity such as scenario planning (Bodwell and Chermack, 2010).

At first glance, the farming sector may be seen as specific in relation to some characteristics (complexity of the objects managed, variability of living organisms, multiple uncertainties, complex and distributed organization of knowledge production, etc.). Nevertheless, its current challenges related to the ecologization of agricultural production encourages us to imagine parallels with other sectors that share the same specificities, such as health or environment. They all raise questions at the core of the KM community such as the generation of knowledge through action, the necessity of revisiting knowledge sharing models or, more broadly, the multiple relationships between innovation and knowledge management that prompt us to cross the permeable boundary between science and practice.

\section{REFERENCES}

Agrawal, A. (1995), "Dismantling the Divide Between Indigenous and Scientific Knowledge", Development and Change, Vol.26 No. 3, pp. 413-439.

Agterberg, M., Van den Hooff, B., Huysman, M., and Soekijad, M. (2010), "Keeping the wheels turning: The dynamics of managing networks of practice", Journal of Management Studies, Vol. 47 No.1, pp. 85-108.

Ajayi, O. C. (2007), "User acceptability of sustainable soil fertility technologies: Lessons from farmers' knowledge, attitude and practice in southern Africa", Journal of Sustainable Agriculture, Vol. 30 No. 3, pp. 21-40.

Anchirinah, V. M., Yiridoe, E. K., and Bennett-Lartey, S. O. (2001) "Enhancing sustainable production and genetic resource conservation of bambara groundnut: a survey of indigenous agricultural knowledge systems", Outlook on Agriculture, Vol. 30 No. 4, pp. 281-288.

Baars, T. (2011), "Experiential science; towards an integration of implicit and reflected practitioner-expert knowledge in the scientific development of organic farming", Journal of agricultural and environmental ethics, Vol. 24 No. 6, pp. 601-628.

Barbier, M., and Elzen, B. (2012), System Innovations, Knowledge Regimes, and Design Practices towards Transitions for Sustainable Agriculture. Paris : INRA Editions.

Barrios, E., Delve, R. J., Bekunda, M., Mowo, J., Agunda, J., Ramisch, J., ... and Thomas, R. J. (2006), "Indicators of soil quality: A South-South development of a methodological guide for linking local and technical knowledge", Geoderma, Vol. 135, pp. 248-259.

Bate, S.P. and Robert, G. (2002), "Knowledge Management and communities of practice in the private sector: lessons for modernising the National Health Service in England and Wales", Public Administration, Vol. 80 No. 4, pp. 643-663.

Belgrave, B. R., Watt, P. C., Brock, J. L., Wewala, S., \& Sedcole, J. R. (1990), “A survey of farmer knowledge and use of pasture cultivars in New Zealand”, New Zealand journal of agricultural research, Vol. 33 No. 2, pp.199-211.

Bell, M. M., Lyon, A., Gratton, C., and Jackson, R. D. (2008), "Commentary: The productivity of variability: an agroecological hypothesis”, International Journal of Agricultural Sustainability, Vol. 6 No. 4, pp. 233-235.

Bierly, P., \& Chakrabarti, A. (1996), "Generic knowledge strategies in the US pharmaceutical industry", Strategic management journal, Vol. 17 No.S2, pp. 123-135.

Binh, D. K. N. T., Phuong, L. T., Douglas, I., Van De, N., McMorrow, J., Lindley, S., ... and Tho, N. (2008), "Local knowledge and economic realities affecting soil erosion in the rach rat catchment, Vietnam", Geographical Research, Vol. 46 No.1, pp. 17-26.

Bodwell, W., and Chermack, T. J. (2010), "Organizational ambidexterity: Integrating deliberate and emergent strategy with scenario planning", Technological Forecasting and Social Change, Vol. 77 No. 2, pp. 193-202.

Bollig, M., and Schulte, A. (1999), "Environmental change and pastoral perceptions: degradation and indigenous knowledge in two African pastoral communities", Human ecology, Vol. 27 No. 3, pp. 493-514.

Bonny, B. P., and Vijayaragavan, K. (2001), "Evaluation of indigenous knowledge systems of traditional rice farmers in India”, Journal of sustainable Agriculture, Vol. 18 No.4, pp. 39-51. 
Briggs, J, Badri, M, and Mekki, AM (2009), "Indigenous knowledges and vegetation use among bedouin in the Eastern Desert of Egypt", Applied Geography, Vol.19, pp. 78-103.

Briggs, J. (2013), "Indigenous knowledge: a false dawn for development theory and practice?", Progress in Development Studies. vol. 13, no 3, pp. 231-243.

Briggs, J., and Moyo, B. (2012), "The Resilience of Indigenous Knowledge in Small-scale African Agriculture: Key Drivers", Scottish Geographical Journal, Vol. 128 No. 1, pp. 64-80.

Briggs, J., and Sharp, J. (2004), "Indigenous knowledges and development: a postcolonial caution", Third World Quarterly, Vol. 25 No. 4, pp. 661-676.

Briggs, J., Pulford, I. D., Badri, M., and Shaheen, A. S. (1998), "Indigenous and scientific knowledge: the choice and management of cultivation sites by Bedouin in Upper Egypt", Soil Use and Management, Vol. 14 No. 4, pp. 240-245.

Bruckmeier, K., and Tovey, H. (2008), "Knowledge in sustainable rural development: from forms of knowledge to knowledge processes", Sociologia Ruralis, Vol. 48 No. 3, pp. 313-329.

Cabero J., and van Immerzeel W., (2007), "Building learning networks for small-scale farmers: Pachamama Raymi as an innovative knowledge management system", Knowledge Management for Development Journal, Vol. 3 No. 2, pp. 52-63.

Calvo-Iglesias, M. S., Crecente-Maseda, R., and Fra-Paleo, U. (2006), "Exploring farmer's knowledge as a source of information on past and present cultural landscapes: a case study from NW Spain", Landscape and Urban Planning, Vol. 78 No. 4, pp. 334-343.

Choi, B., and Lee, H. (2002), "Knowledge management strategy and its link to knowledge creation process", Expert Systems with applications, Vol. 23 No. 3, pp. 173-187.

Chowdhury, A.H., Van Mele, P. and Hauser, M. (2011), "Contribution of farmer-to-farmer video to capital assets building: Evidence from Bangladesh”, Journal of Sustainable Agriculture, Vol. 35 No. 4, pp. 408-435.

Cohendet P., and Llerena P. (2005), "A dual theory of the firm between transaction and competences: conceptual analysis and empirical considerations", Revue d'Economie Industrielle, n¹10, 2ème trim, pp.175-198.

Cowan, R., David, P., and Foray, D., (2000), "The Explicit Economics Of Knowledge Codification and Tacitness", Industrial and Corporate Change, vol. 9, no 2, p. 211-253.

Dawoe, E. K., Quashie-Sam, J., Isaac, M. E., and Oppong, S. K. (2012), "Exploring farmers' local knowledge and perceptions of soil fertility and management in the Ashanti Region of Ghana", Geoderma, Vol. 179, pp. 96-103.

Denford, J. S., and Chan, Y. E. (2011), "Knowledge strategy typologies: defining dimensions and relationships", Knowledge Management Research \& Practice, Vol. 9 No. 2, pp. 102-119.

Ditillo, A. (2004), "Dealing with uncertainty in knowledge-intensive firms: the role of management control systems as knowledge integration mechanisms", Accounting, Organizations and Society, Vol. 29 No. 3, pp. 401-421.

Dixon, H., Doores, J.W., Joshi, L., and Sinclair, F.L. (1999), “Agroforestry Knowledge Toolkit for Windows: methodological guidelines, computer software and manual for WinAKT". School of Agricultural and Forest Sciences, University of Wales, Bangor.

Doré T., Makowski D., Malézieux E., Munier-Jolain N.,Tchamitchian M., and Tittonell P. (2011), "Facing up to the paradigm of ecological intensification in agronomy: Revisiting methods, concepts and knowledge", European Journal of Agronomy, Vol. 34, pp. 197-210.

Earl, M. (2001), "Knowledge management strategies: toward a taxonomy”, J. of Management Information Systems, Vol 18 No 1, pp. 215-242.

Ergazakis, K., Metaxiotis, K., and Askounis, D. (2013), "Knowledge-based development research: a comprehensive literature review 2000-2010", Knowledge Management Research \& Practice, Vol. 11 No. 1, pp. 78-91.

Ermine J.L., (2000), «Les systèmes de connaissance ». Hermès, Paris.

Fagbemissi, R., and Price, L. L. (2008), "HIV/AIDS orphans as farmers: uncovering pest knowledge differences through an ethnobiological approach in Benin”, NJAS-Wageningen Journal of Life Sciences, Vol. 56 No. 3, pp. 241-259.

Fernández-Giménez, M. E., and Estaque, F.F. (2012), "Pyrenean pastoralists' ecological knowledge: Documentation and application to natural resource management and adaptation", Human Ecology, Vol. 40 No. 2, pp. 287-300.

Filippini, R., Güttel, W. H., and Nosella, A. (2012), "Ambidexterity and the evolution of knowledge management initiatives", Journal of Business Research, Vol. 65 No. 3, pp. 317-324.

Galindo I.M., (2007), "Regional development through knowledge creation in organic agriculture", Journal of Knowledge Management, Vol. 11 No. 5, pp. 87-97.

Ghorbani, M., Azarnivand, H., Mehrabi, A. A., Jafari, M., Nayebi, H., and Seeland, K. (2013), "The Role of Indigenous Ecological Knowledge in Managing Rangelands Sustainably in Northern Iran”, Ecology and Society, Vol. 18 No. 2.

Gibbon D., (1994), "Farming Systems Research/extension: background concepts, experience and networking" In Dent et McGregor (Ed). Rural and farming systems analysis. European perspectives. CAB International. Pp 3-18.

Gilles, JL, Thomas, JL, Valdivia, C, and Yucra, ES (2013), "Laggards or Leaders: Conservers of Traditional Agricultural Knowledge in Bolivia”, Rural Sociology, Vol. 78 No. 1, pp. 51-74.

Girard N., (2013), “Categorizing stakeholders' practices with repertory grids for sustainable development”, M@n@gement, Vol. 16 No. 1, pp. 31-48.

Girard N., (2014), "Quels sont les nouveaux enjeux de gestion des connaissances ? L'exemple de la transition écologique des systèmes agricoles", Revue internationale de psychosociologie et de gestion des comportements organisationnels, Vol. 49 No. XIX, pp. 51-78. 
Girard N., and Navarrete M. (2005), "Quelles synergies entre connaissances scientifiques et empiriques ? L'exemple des cultures du safran et de la truffe", Natures Sciences Sociétés, Vol. 13 No.1, pp. 33-44.

Glaser, B. G., and Strauss, A. L. (2009), "The discovery of grounded theory: Strategies for qualitative research" Transaction Books.

Gómez L.F., Ríos-Osorio L., and Eschenhagen M.L., (2013), "Agroecology publications and coloniality of knowledge", Agronomy for Sustainable Development, Vol. 33, pp. 355-362.

Gordon, R., and Grant, D. (2013), "Knowledge management or management of knowledge? Why people interested in knowledge management need to consider Foucault and the construct of power", Tamara Journal for Critical Organization Inquiry, vol. 3, no 2 .

Haggie, K., and Kingston, J. (2003), "Choosing your knowledge management strategy", Journal of Knowledge Management Practice, Vol. 4 No. 4.

Hansen,M.T., N.Nohria, and T.Tierney, (1999), "What's Your Strategy for Managing Knowledge?", Harvard Business Review, Vol March-April, pp. 106-116.

Hashemi, S. M., Mokhtarnia, M., Erbaugh, J. M., and Asadi, A. (2008), "Potential of extension workshops to change farmers' knowledge and awareness of IPM", Science of the total environment, Vol. 407 No. 1, pp. 84-88.

Hedlund, G. (1994), "A model of knowledge management and the N-form corporation", Strategic management journal, Vol. 15 No. S2, pp. 73-90.

Hernández-Hernández, R.M., Morros, M.E., Bravo, C., Lozano, Z., Herrera P., Ojeda, A., Morales J., Birbe, B. (2011), "La integración del conocimiento local y científico en el manejo sostenible de suelos en agroecosistemas de sabanas", Interciencia, Vol. 36 No. 2, pp. 104-112.

Hiruy, K., and Eversole, R. (2013), "Participation at the coalface: translating local knowledges and institutions in post-war Tigray, North Ethiopia", Community Development Journal, Vol. 48 No. 2, pp. 215-231.

IAASTD, (2008), "Agriculture at a crossroads", International Assessment of Agricultural Knowledge, Science and Technology for Development. Washington DC: UNDP.

Ingram, J. (2008), "Are farmers in England equipped to meet the knowledge challenge of sustainable soil management? An analysis of farmer and advisor views", Journal of environmental management, Vol. 86 No. 1, pp. 214-228.

Isaac, M. E., Erickson, B. H., Quashie-Sam, S. J., and Timmer, V. R. (2007), "Transfer of knowledge on agroforestry management practices: the structure of farmer advice networks", Ecology and Society, Vol. 12 No. 2.

Kamara, J. M., Anumba, C. J., and Carrillo, P. M. (2002), "A CLEVER approach to selecting a knowledge management strategy", International journal of project management, Vol. 20 No. 3, pp. 205-211.

Kaup, B. Z. (2008), "The Reflexive Producer: The Influence of Farmer Knowledge Upon the Use of Bt Corn”, Rural Sociology, Vol. 73 No. 1, pp. 62-81.

Kiptot, E., Franzel, S., Hebinck, P., and Richards, P. (2006), "Sharing seed and knowledge: farmer to farmer dissemination of agroforestry technologies in western Kenya", Agroforestry Systems, Vol. 68 No. 3, pp. 167-179.

Kolb, D.A. (1984), "Experiential learning: experience as the source of learning and development", Englewood Cliffs, NJ: Prentice Hall.

Langenberger, G., Prigge, V., Martin, K., Belonias, B., and Sauerborn, J. (2009), "Ethnobotanical knowledge of Philippine lowland farmers and its application in agroforestry", Agroforestry systems, Vol. 76 No. 1, pp. 173-194.

Lewis, C. P., Newell, J. N., Herron, C. M., and Nawabu, H. (2010), "Tanzanian farmers' knowledge and attitudes to GM biotechnology and the potential use of GM crops to provide improved levels of food security. A Qualitative Study", $B M C$ public health, Vol. 10 No. 1, p 407.

Lyon,A., M.M.Bell, C.Gratton, and R.Jackson (2011), "Farming without recipe: Wisconsin graziers and new directions for agricultural science", Journal of Rural Studies, Vol. 27, pp. 384-393.

March, J. G. (1991), "Exploration and exploitation in organizational learning”, Organization science, Vol. 2 No. 1, pp. 71-87. Marie, C. N., Sibelet, N., Dulcire, M., Rafalimaro, M., Danthu, P., and Carrière, S. M. (2009), "Taking into account local practices and indigenous knowledge in an emergency conservation context in Madagascar", Biodiversity and Conservation, Vol. 18 No. 10, pp. 2759-2777.

Marin H.M., (2011), «La protection légale des connaissances traditionnelles des peuples autochtones Mapuches, par rapport à l'utilisation des organismes génétiquement modifiés (OGM) au Chili » Thèse en droit, Université de Montréal.

Millar J., and Curtis A. (1999), "Challenging the boundaries of local and scientific knowledge in Australia: Opportunities for social learning in managing temperate upland pastures", Agriculture and Human Values, Vol. 16 No. 4, pp. 389-399.

Morris, C. (2006), "Negotiating the boundary between state-led and farmer approaches to knowing nature: an analysis of UK agri-environment schemes", Geoforum, Vol. 37 No. 1, pp. 113-127.

Munyua, H. M., and Stilwell, C. (2013), "Three ways of knowing: Agricultural knowledge systems of small-scale farmers in Africa with reference to Kenya", Library \& Information Science Research, Vol. 35 No. 4, pp. 326-337.

Murdoch,J., and J.Clark., (1994), "Sustainable knowledge", Geoforum, Vol. 25 No.2, pp. 115-132.

Nampanya, S., Suon, S., Rast, L., and Windsor, P. A. (2012), "Improvement in smallholder farmer knowledge of cattle production, health and biosecurity in Southern Cambodia between 2008 and 2010", Transboundary and emerging diseases, Vol. 59 No. 2, pp. 117-127.

Nonaka I., and Takeuchi H., (1995), "The knowledge creating company: how Japanese companies create the dynamics of innovation", New York: Oxford University Press. 
Nowotny H., Scott P., and Gibbons M.T., (2001), "Re-Thinking Science: Knowledge and the Public in an Age of Uncertainty". Blackwell Publisher.

Nyeko, P., Edwards-Jones, G., Day, R. K., and Raussen, T. (2002), "Farmers' knowledge and perceptions of pests in agroforestry with particular reference to Alnus species in Kabale district, Uganda”, Crop protection, vol. 21 No. 10, pp. 929941.

Nygren, A. (1999), "Local Knowledge in the Environment-Development Discourse From dichotomies to situated knowledges", Critique of anthropology, Vol. 19 No. 3, pp. 267-288.

Oliver, Y. M., Robertson, M. J., and Wong, M. T. F. (2010), "Integrating farmer knowledge, precision agriculture tools, and crop simulation modelling to evaluate management options for poor-performing patches in cropping fields", European Journal of Agronomy, Vol. 32 No. 1, pp. 40-50.

Ouédraogo, S., and Bertelsen, M. K. (1998), "The value of research on indigenous knowledge: Preliminary evidence from the case of zai in Burkina Faso", Journal of Sustainable Agriculture, Vol. 10 No. 1, pp. 33-42.

Pesqueux Y., (2009), "Une critique du Knowledge Management", In D.Golsorkhi, I.Huault, and B.Leca (ed.) Les études critiques en management. Une perspective française. Presses Universitaires de Laval, pp. 361-378.

Polanyi M., (1966), "The Tacit Dimension”, University of Chicago Press: Chicago

Power, E. F., Kelly, D. L., and Stout, J. C. (2013), "Impacts of organic and conventional dairy farmer attitude, behaviour and knowledge on farm biodiversity in Ireland", Journal for Nature Conservation, Vol. 21 No. 5, pp. 272-278.

Price L.L. (2001), "Demystifying farmers' entomological and pest management knowledge: a methodology for assessing the impacts on knowledge from IPM-FFS and NES interventions", Agriculture and HumanValues, vol. 18 no 2, pp. 153-176

Raisch, S, J. Birkenshaw, G. Probst, M.L. Tushman, (2009), "Organizational Ambidexterity : Balancing Exploitation and Exploration for Sustained Performance”, Organization Science, Vol. 20 No. 4, pp. 685-695.

Rerup Schlichter, B., and Kraemmergaard, P. (2010), "A comprehensive literature review of the ERP research field over a decade”, Journal of Enterprise Information Management, Vol. 23 No. 4, pp. 486-520.

Riley, M. (2008), "Experts in their fields: farmer-expert knowledges and environmentally friendly farming practices", Environment and Planning A, Vol. 40 No. 6, p 1277.

Ríos-González, A., Jansen, K., and Javier Sánchez-Pérez, H. (2013), "Pesticide risk perceptions and the differences between farmers and extensionists: Towards a knowledge-in-context model", Environmental research, Vol. 124, pp. 43-53.

Roberts J. (2013), "Organizational ignorance: Towards a managerial perspective on the unknown", Management Learning, vol. 44 no. 3 , pp. 215-236.

Röling N., (1988), "Extension science. Information systems in agricultural development”, Cambridge University Press.

SCAR-CWG, (2010), "Draft Reflection Paper on Agricultural Knowledge and Information Systems”, August 2010.

Scheepers R., Venkitachalam K., and Gibbs M.R., (2004), "Knowledge strategy in organizations: refining the model of Hansen, Nohria and Tierney”, Journal of Strategic Information Systems, vol. 13, pp. 201-222.

Schmidt, B.H. (1999), "Experiential Marketing: How to Get Customers to SENSE, FEEL, THINK, ACT and RELATE to Your Company and Brands", New York: The Free Press.

Shahvali, M., and Zarafshani, K. (2002), "Using PRA techniques as metacognitive strategies to develop indigenous knowledge-a case study", International Social Science Journal, Vol. 54 No. 173, pp. 413-419.

Shepherd C.J. (2010), "Mobilizing Local Knowledge and Asserting Culture", Current Anthropology, Vol. 51 No. 5, pp. 629654.

Sligo, F. X., and Massey, C. (2007), "Risk, trust and knowledge networks in farmers' learning", Journal of Rural Studies, Vol. 23 No. 2, pp. 170-182.

Soulignac, V, Ermine, J, Paris, J, Devise, O and Chanet, J.P., (2012), “A Knowledge Management System for Exchanging and Creating Knowledge in Organic Farming", The Electronic Journal of Knowledge Management, Vol. 10 No. 2, pp. 163182.

Speranza, C. I., Kiteme, B., Ambenje, P., Wiesmann, U., and Makali, S. (2010), Indigenous knowledge related to climate variability and change: insights from droughts in semi-arid areas of former Makueni District, Kenya", Climatic Change, Vol. 100 No. 2, pp. 295-315.

Srang-iam, W. (2013), "Decontextualized Knowledge, Situated Politics: The New Scientific-Local Politics of Rice Genetic Resources in Thailand", Development and Change, Vol. 44 No. 1, pp. 1-27.

Swan, J., Newell, S., Scarbrough, H., and Hislop, D. (1999), "Knowledge management and innovation: networks and networking", Journal of Knowledge management, Vol. 3 No. 4, pp. 262-275.

Thomas,D.S.G., and C.Twyman, (2004), "Good or bad rangeland? Hybrid knowledge, science, and local understandings of vegetation dynamics in the Kalahari”, Land Degradation \& Development, Vol. 15 No. 3, pp. 215-231.

Tsoukas H., and Vladimirou E., (2001), “What is organizational knowlegde ?”, Journal of Management Studies, Vol. 38 No. 7, pp. 973-993.

Tripp, R. (1993), "Invisible hands, indigenous knowledge and inevitable fads: challenges to public sector agricultural research in Ghana", World Development, Vol. 21 No. 12, pp. 2003-2016.

Van de Ven, A. H., and Johnson, P. E. (2006), "Knowledge for theory and practice", Academy of management review, Vol. 31 No. 4, pp. 802-821.

Walker D.H., Sinclair, F.L. and Kendon, G., (1995), “A knowledge based systems approach to agroforestry research and extension", AI Applications, Vol. 9 No. 3, pp. 61-72. 
Wenger E, (1998), “Communities of Practice: Learning, Meaning, and Identity”, Cambridge University Press.

WinklerPrins A.M.G.A., and J.A. Sandor J.A. (2003), "Local soil knowledge: insights, applications, and challenges", Geoderma, Vol. 111 No. 3-4, pp. 165-170.

Wyckhuys, K. A., and O’Neil, R. J. (2007), “Local agro-ecological knowledge and its relationship to farmers' pest management decision making in rural Honduras", Agriculture and Human Values, Vol. 24 No. 3, pp. 307-321.

\footnotetext{
i Between researchers who produce universal knowledge and farmers who are expected to be the "appliers" of innovations seen as the final products of fundamental research, via applied research and development

ii See the documents published by the World Bank (e.g., "Indigenous knowledge for development - A framework for action", 1998) and databases such as the Traditional Knowledge World Bank (http://www.tkwb.org/web/?page_id=4)

iii As underlined in the editorial of the special issue of Geoderma in 2003 devoted to ethnopedology: "the increased acceptance of ethnopedology and local soil knowledge within science" (WinklerPrins, 2003)

${ }^{\text {iv }}$ In the editorial policy of the journal IJTK, traditional knowledge is considered to be valid and characterized as "passed down by word of mouth, from generation to generation and is, for the most part, undocumented"

${ }^{v}$ That we can question in terms of the "colonialism of knowledge production" observed by Gomez et al. (2013) in relation to publications on agroecology. However, to do so, it would be necessary to analyze the countries that the authors are affiliated with and the journals that publish their articles, for our four groups
} 